\title{
AN Alternative APPROACH FOR ESTIMATING GDP GROWTH RATE: FuzZY PREDiction MODEL
}

\author{
Simona Hašková \\ Institute of Technology and Business, School of Expertness and Valuation, \\ Okružní 517/10, 37001 České Budějovice, Czech Republic \\ e-mail: haskovas@ post.cz
}

\begin{abstract}
The inaccuracy of the predictions of the future growth rate of output is due to the lack of information needed to eliminate uncertainty. The aim of the paper is to predict the growth rate of the output within a short time period using the fuzzy approach, which is an appropriate tool for analyzing problems burdened by uncertainty. First, we briefly compare the fuzzy approach with the statistical methods in the cases where predictors face a non-deterministic environment. The principles of the fuzzy set theory is described and then applied in the gross domestic product growth rate prediction of Greece for the years 2018 (compared to the reported econometric forecast) and 2020 (a new contribution to the paper). The forecasts lean on the input components of the previous four-year development of three macroeconomic indicators (long-term interest rates, investments and unemployment) published in the OECD.stat, which are the basal input parameters of the task. The fuzzy prediction results showed no significant deviations from the statistical predictions. Nevertheless, the model input data monotonic development enabled us to demonstrate one of the ways by means of which the experts can correct the deficiencies of the fuzzy algorithm. Herein identified deficiency is the missing information originating from the input data, which the fuzzy algorithm did not work with. The appropriate corrective measure of the fuzzy model has been chosen and applied.
\end{abstract}

\section{Keywords}

Short-term prediction; Non-deterministic environment; Fuzzy approach; Expert knowledge.

\section{Introduction}

The inaccuracy of the outcome of the prediction of the future growth rate of any state output is due to the lack of information needed to the complete elimination of uncertainty we face in every non-deterministic environment. This uncertainty is associated with both the inputs to the prediction model and its functioning. In the first case, we talk about "external" uncertainty stemming from the incomplete knowledge of the relevant values of known factors entering the prediction model (López-Duarte \& Vidal-Suárez, 2010). They, together with the unknown values and therefore not considered factors in the model, influence the future growth rate of the output. In the latter case, we talk about the "inner" uncertainty stemming from the approximate character of the formal description of the considered relationships between inputs and outputs of the prediction model (Bloom, 2009). In each of these cases, we can encounter the uncertainty of two different kinds. The uncertainty in terms of randomness, whose objectively identified basic statistical characteristics are known, and uncertainty in the sense of "fuzziness", which predominantly derives from the vagueness of the terms (e.g., few, little, approximately, a little, essentially, simply, complexly, significantly, analogously, etc.) 
occurring in the description of the situation and indicating the subjective understanding of intuitive concepts (Herrera \& Herrera-Viedma, 2000; Cabrerizo et al., 2015).

Econometrics silently identifies uncertainty with randomness by considering the existing uncertain alternatives as equally probable in the context of the indifference principle (see Dubois, 2006) and building the prediction models solely on the basis of the probability theory and mathematical statistics (see e.g., Timmermans et al., 2017 or Vochozka et al., 2019). Observed data sets are represented by a system of impartial point estimates of selected characteristics (statistics) from which the predictive model derives a statistically expected value of the result. The sophisticated and complicated multiple regression algorithms help to extract as much information as possible from the available data.

However, a number of system theory authorities (see, for example, Zadeh (1996) or Herrera et al. (2009)) call into question the effectiveness of decision-making and management procedures based on the approximation of uncertainty with randomness. In terms of uncertainty, their works operate with the terms of linguistic variables formalized by fuzzy sets instead of the numerical values of random variables. Zadeh's work conception of terms as representatives of intuitive concepts is in line with Kahneman's conception of the functioning of the human mind (see Kahneman, 2003).

The aim of the paper is to present the fuzzy algorithm of the short-term prediction of the output growth rate operating under conditions of inner uncertainty and formulated within Zadeh's fuzzy approach offering subjectively expected values as an alternative to statistically expected values. It deals with the fuzzy algorithm of the progression of the time series, specified in the methodological part, which is preceded by a brief discussion of the basic principles of the fuzzy approach. In the application section, the fuzzy algorithm is used for the estimation of the GDP growth rate of Greece in 2018 (the comparison with the published econometric forecast) and 2020 (a contribution to the paper).

\section{$1 \quad$ Methods of Research: The Fuzzy Approach}

The fuzzy approach can be traced in different versions of fuzzy logic, which was formed by adapting the binary numerical characteristics of the proposition operators to the interval $\langle 0.1\rangle$ (Hašková \& Fiala, 2019). The fuzzy logic performs a tool for handling fuzzy sets, the theory of which was published by Zadeh (1973).

\subsection{Principles of the Fuzzy Set Theory}

Let the set $U$ be a field of consideration or discussion. Let $\mu_{\underline{A}}: U \rightarrow\langle 0,1\rangle$ be a membership function and let $\underline{A}=\left\{\left(y, \mu_{\underline{A}}(y)\right): y \in U\right\}$ be a set of all pairs $\left(y, \mu_{\underline{A}}(y)\right)$ in which the numbers 0 $\leq \mu_{\underline{A}}(y) \leq 1$ assign to the given $y \in U$ a membership degree of the pair $\left(y, \mu_{\underline{A}}(y)\right)$ to the set $\underline{A}$. Then $\underline{A}$ is a fuzzy subset on the universe $U$. The significant characteristic of fuzzy subset $\underline{A}$ is its support $U_{\underline{A}}=\left\{y: 0<\mu_{\underline{A}}(y) \leq 1, y \in U\right\} \subset U$. In terms of fuzzy logic $\mu_{\underline{A}}(y)=\left|y \in U_{\underline{A}}\right|$. The element $y \in \bar{U}$ with $\mu_{\underline{A}}(y)=0.5$ is called the crossover point in $\underline{A}$. In the case of values greater than 0.5 , the element $y$ rather belongs to $U_{\underline{A}}$, in the case of the smaller ones it rather does not belong to it (Dubois \& Prade, 1996).

In this paper, the numerical fuzzy sets are formal representations of terms of linguistic variables. For our purpose, the model with one internal and two border fuzzy sets for the terms low $(\underline{L})$, common $(\underline{M})$, and high $(\underline{H})$ value is suitable. Interval $U$ is divided with the points a, b, c, d into five sections with the following membership functions (1):

$$
\begin{aligned}
& \mu \mathrm{L}(\mathrm{y})=1 \text { for } \mathrm{y}<\mathrm{a}, \\
& \mu \mathrm{L}(\mathrm{y})=(\mathrm{b}-\mathrm{y}) /(\mathrm{b}-\mathrm{a}) \text { for } \mathrm{a} \leq \mathrm{y}<\mathrm{b},
\end{aligned}
$$


$\mu \mathrm{L}(\mathrm{y})=0$ otherwise

$\mu \mathrm{M}(\mathrm{y})=(\mathrm{y}-\mathrm{a}) /(\mathrm{b}-\mathrm{a})$ for $\mathrm{a} \leq \mathrm{y}<\mathrm{b}$,

$\mu \mathrm{M}(\mathrm{y})=1$ for $\mathrm{b} \leq \mathrm{y}<\mathrm{c}$,

$\mu \mathrm{M}(\mathrm{y})=(\mathrm{d}-\mathrm{y}) /(\mathrm{d}-\mathrm{c})$ for $\mathrm{c} \leq \mathrm{y}<\mathrm{d}$,

(H)

$\mu \mathrm{M}(\mathrm{y})=0$ otherwise.

$\mu \mathrm{H}(\mathrm{y})=0$ for $\mathrm{y}<\mathrm{c}$,

$\mu \mathrm{H}(\mathrm{y})=(\mathrm{y}-\mathrm{c}) /(\mathrm{d}-\mathrm{c})$ for $\mathrm{c} \leq \mathrm{y}<\mathrm{d}$,

$\mu \mathrm{H}(\mathrm{y})=1$ otherwise.

The expert determines the position of the points $\mathrm{a}, \mathrm{b}, \mathrm{c}$ and $\mathrm{d}$ in the universe $U$. In the case of their regular distribution, we get the courses of the functions $\mu$ shown in Figure 1 in section 2 . From it we see that the linguistic variable acquires the values at two levels: at the level of the basal values $y$ in the universe $U$ and at the level of terms (intuitive concepts) as fuzzy subsets of $\underline{L}, \underline{M}, \underline{H}$ in the universe $U$. Each of these terms is defined by its membership function $\mu_{\underline{L}}$, $\mu_{\underline{M}}, \mu_{\underline{H}}$ over the field of its support, which is a subset of $U$.

Another important tool of the fuzzy set theory is the rule. In our considered model with $\mathrm{n}$ input linguistic variables and one output linguistic variable it is an element $\left(\left(\underline{A}_{1, \ldots}, \underline{A}_{\mathrm{n}}\right), \underline{C}\right)$ of the relation $F \subset\left(\left\{\underline{L}_{1}, \underline{M}_{1}, \underline{H}_{1}\right\} \times \ldots \times\left\{\underline{L}_{\mathrm{n}}, \underline{M}_{\mathrm{n}}, \underline{H}_{\mathrm{n}}\right\}\right) \times\{\underline{L}, \underline{M}, \underline{H}\}$, which is a projection $F:\left(\left\{\underline{L}_{1}\right.\right.$, $\left.\left.\underline{M}_{1}, \underline{H}_{1}\right\} \times \ldots \times\left\{\underline{L}_{\mathrm{n}}, \underline{M}_{\mathrm{n}}, \underline{H}_{\mathrm{n}}\right\}\right) \rightarrow\{\underline{L}, \underline{M}, \underline{H}\}$ in the form of $F\left(\underline{A}_{1}, \ldots, \underline{A}_{\mathrm{n}}\right)=\underline{C}$, where $\underline{C} \in\{\underline{L}, \underline{M}, \underline{H}\}$ and $\underline{A}_{\mathrm{i}} \in\left\{\underline{L}_{\mathrm{i}}, \underline{M}_{\mathrm{i}}, \underline{H}_{\mathrm{i}}\right\}, \mathrm{i}=1, \ldots, \mathrm{n}$. The n-tuple of terms $\left(\underline{A}_{1, \ldots} \underline{A}_{\mathrm{n}}\right)$ is the left side of the rule, the term $F\left(\underline{A}_{1}, \ldots, \underline{A}_{\mathrm{n}}\right)$ is the right side of the rule. The relation $F$ has a maximum of $\mathrm{n}^{3}$ elements. We call it a set of inferential rules (Běhounek \& Cintula, 2006).

One of the basic concepts of the fuzzy set theory is the so-called extension principle (in detail see Kahraman, 2008). Our modification of the extension principle is based on the following steps:

- Fuzzification in which the input vector $x=\left(x_{1}, \ldots, x_{\mathrm{n}}\right)$ converts each inference rule from the set $P$ into the logical notation mode.

- A set of partial results is a set $B=\left\{\min \left\{\min \left\{\mu_{1}\left(x_{1}\right), \ldots, \mu_{\mathrm{n}}\left(x_{\mathrm{n}}\right)\right\}, \mu_{\underline{B}}\right\}:\left(\min \left\{\mu_{1}\left(x_{1}\right), \ldots\right.\right.\right.$, $\left.\left.\left.\mu_{\mathrm{n}}\left(x_{\mathrm{n}}\right)\right\}, \mu_{\underline{B}}\right) \in P^{*}\right\}$.

- Aggregation or summation of functions of set $B$ into a compact unit and its aggregate $\mu_{\text {agg }}$ detection; this compact unit is a fuzzy subset on the universe $V$ with $\mu_{\text {agg }}=$ $\max \left\{\min \left\{\min \left\{\mu_{1}\left(x_{1}\right), \ldots, \mu_{\mathrm{n}}\left(x_{\mathrm{n}}\right)\right\}, \mu_{\underline{B}}\right\}:\left(\min \left\{\mu_{1}\left(x_{1}\right), \ldots, \mu_{\mathrm{n}}\left(x_{\mathrm{n}}\right)\right\}, \mu_{\underline{B}}\right) \in P^{*}\right\}$.

- Defuzzification, which transforms the result from the level of terms (the function $\mu_{A G G}(y)$ of the fuzzy set $\left.\underline{A G G}\right)$ into $y_{0} \in Y$ in the space of basal values of the output linguistic variable. We ascertain the basal value $y_{0}$ as the horizontal coordinate of the center of gravity of the area under the course of the function $\mu_{A G G}(y)$. Thus:

$$
y_{0}=\int y \cdot \mu_{\underline{A G G}}(y) \mathrm{d} y / \int \mu_{\underline{A G G}}(y) \mathrm{d} y
$$

where $\int$ is the symbol of a certain integral over the universe $Y$.

Since the resulting constant $y_{0}$ is largely the result of the subjective experience and opinions of experts who created the model, we call it a subjectively expected value.

\subsection{Task Assumptions and Input Data}

The formulation of the fuzzy prediction model of the next time series member has its own specificity consisting of the fact that previous members of the resulting series are known (the historically measured values). Specifically, in the case of the GDP growth prediction it is 
possible to estimate the phase of the current GDP development (decline, depression, growth, stable boom, etc.). We also know the previous part of the baseline values of several linguistic variables, on which GDP depends (albeit, largely vaguely). This is reflected in the values of the extreme limits within which we look for the result of the prediction.

Table 1 lists the baseline values of LTI (long-term interest rate), INV (percentage increase in investment), UNE (percentage of unemployment) and the output linguistic variable $\Delta \mathrm{GDP} \%$ (the GDP growth rate) of Greece between the years 2010 and 2017 and their econometric forecasts in 2018 and 2019 (the color-highlighted columns in Tab. 1).

Tab. 1: Input macroeconomic data for the fuzzy short term prediction model of GDP growth

rate in Greece
\begin{tabular}{|l|r|r|r|r|r|r|r|r|r|r|}
\hline Year & $\mathbf{2 0 1 0}$ & $\mathbf{2 0 1 1}$ & $\mathbf{2 0 1 2}$ & $\mathbf{2 0 1 3}$ & $\mathbf{2 0 1 4}$ & $\mathbf{2 0 1 5}$ & $\mathbf{2 0 1 6}$ & $\mathbf{2 0 1 7}$ & $\mathbf{2 0 1 8}$ & $\mathbf{2 0 1 9}$ \\
\hline LTI & 9.1 & 15.7 & 22.5 & 10.1 & 6.9 & 9.7 & 8.4 & 6.1 & 5.3 & 5.1 \\
\hline INV & -19.3 & -20.5 & -23.5 & -8.4 & -4.7 & -0.3 & 1.6 & 3.3 & 7.2 & 7.5 \\
\hline UNE & 12.7 & 17.9 & 24.4 & 27.5 & 26.5 & 24.9 & 23.5 & 21.5 & 20.1 & 18.4 \\
\hline$\Delta$ GDP\% & -5.5 & -9.1 & -7.3 & -3.2 & 0.7 & -0.3 & -0.2 & 1.4 & 2.3 & 2.0 \\
\hline
\end{tabular}

Source: OECD Data: Gross domestic product (GDP), 2018; Investment (GFCF), 2018; Long-term interest rates, 2018; Unemployment rate Total, 2018 - own processing

The opinion of a knowledgeable expert is an important specificity of the fuzzy model formulation; the expert takes his/her knowledge and experience into account through qualified interventions in the model structure and the inference rule formulation (Krueger et al. 2012).

The model works with the dimensionless basal values of the output universe $Y$ and the input universes $U_{\mathrm{LTI}}, U_{\mathrm{INV}}, U_{\mathrm{UNE}}$ located within the interval $\langle 0,100\rangle$ and obtained by converting the given basal values of the respective linguistic variables. The conversion of the inserted basal value $x$ of the universe of the output linguistic variable to the dimensionless value $y \in Y$ is given by the formula $y=100 \cdot\left(x-x_{\min }\right) /\left(x_{\max }-x_{\min }\right)$, where $x_{\max }$ and $x_{\min }$ is the highest and the lowest a priori (subjectively) expected result value respectively. For the conversion in the opposite direction $x=\left(y \cdot\left(x_{\max }-x_{\min }\right) / 100\right)+x_{\min }$ applies.

If the predominant element strategy is chosen in formulating the system of inferential rules with three inputs, then for the conversion of the value $x$ of the universe of the input linguistic variable having a positive or featureless influence on the output linguistic variable it applies that $u=100 \cdot\left(x-x_{\min }\right) /\left(x_{\max }-x_{\min }\right)$. In the case of a negative influence on the output linguistic variable, $u=100-\left(100 \cdot\left(x-x_{\min }\right) /\left(x_{\max }-x_{\min }\right)\right)$ holds.

In both of the latter mentioned cases $x_{\max }$, or respectively, $x_{\min }$ is the highest, or respectively, the lowest given value $x$ within the monitored period.

In our case, the output linguistic variable is the growth rate of the GDP in the year immediately following the monitored period. The percentage increase in investments (INV) increases the growth rate of GDP (a positive effect); high value of interest rates (LTI) tends to decelerate the GDP growth rate (a negative impact); unemployment (UNE) in connection with the real product at the level of its potential has a rather vague effect on the GDP growth rate.

\section{$2 \quad$ Results of the Research}

The course of the $\Delta$ GDP\% (see Table 1) during the period 2014 - 2017 shows a recession phase with a subsequent recovery in 2017 of the Greek economy. The economic growth is expected to continue in the coming years (see European Economic Forecast, 2018). The formulation of the predictive fuzzy model for the year 2018 is based on the characteristics of this period. 
A priori expected value of $\Delta \mathrm{GDP} \%$ for the year 2018 , according to the expert's opinion, is searched for within the limits of the given values $x_{\min }=1, x_{\max }=2.5$; e.g., the conversion of the $\Delta \mathrm{GDP} \%$ value given in 2017 is $y_{17} \approx 27(100 \cdot(1.4-1) /(2.5-1)=26.66)$. Analogously, for the converted values in 2017 of the given inputs the following applies:

- $u_{\mathrm{LTI}}=100-(100 \cdot(6.1-6.1) /(9.7-6.1))=100$;

- $\left.u_{\mathrm{INV}}=100 \cdot(3.3+4.7) /(3.3+4.7)\right)=100$;

- $u_{\mathrm{UNE}}=100-(100 \cdot(21.5-21.5) /(26.5-21.5))=100$.

These outcomes result from the fact that all data uploaded in 2017 are the extreme values (maxima or minima) of the period under consideration. Generally, we can write:

- $u_{\mathrm{LTI}}=100-\left(100 \cdot\left(x_{\min }-x_{\min }\right) /\left(x_{\max }-x_{\min }\right)\right)=100$;

- $\left.u_{\mathrm{INV}}=100 \cdot\left(x_{\max }-x_{\min }\right) /\left(x_{\max }-x_{\min }\right)\right)=100$;

- $u_{\mathrm{UNE}}=100-\left(100 \cdot\left(x_{\min }-x_{\min }\right) /\left(x_{\max }-x_{\min }\right)\right)=100$.

Thus, the triple $(100,100,100) \in U=U_{\mathrm{LTI}} \times U_{\mathrm{INV}} \times U_{\mathrm{UNE}}=\langle 0,100\rangle^{3}$ of internal (converted) input values has been created (see point 1 in section 1.1).

Because of the high external uncertainty (e.g., the uncertain impact on the Greek economy resulting from the approval of the reform package requested by creditors in the framework of the international rescue program - see Council of the European Union, 2018) and internal uncertainty of the model we choose the points $a, b, c, d$ within the interval $\langle 0,100\rangle$ evenly distributed $(a=20, b=40, c=60, d=80)$, (see formula (1) in Section 1.1). Therefore, the courses of the membership functions of the converted output and all the converted inputs are identical (Fig. 1, in which these courses are plotted above the domain of universe $Y$ of converted values of the output linguistic variable):

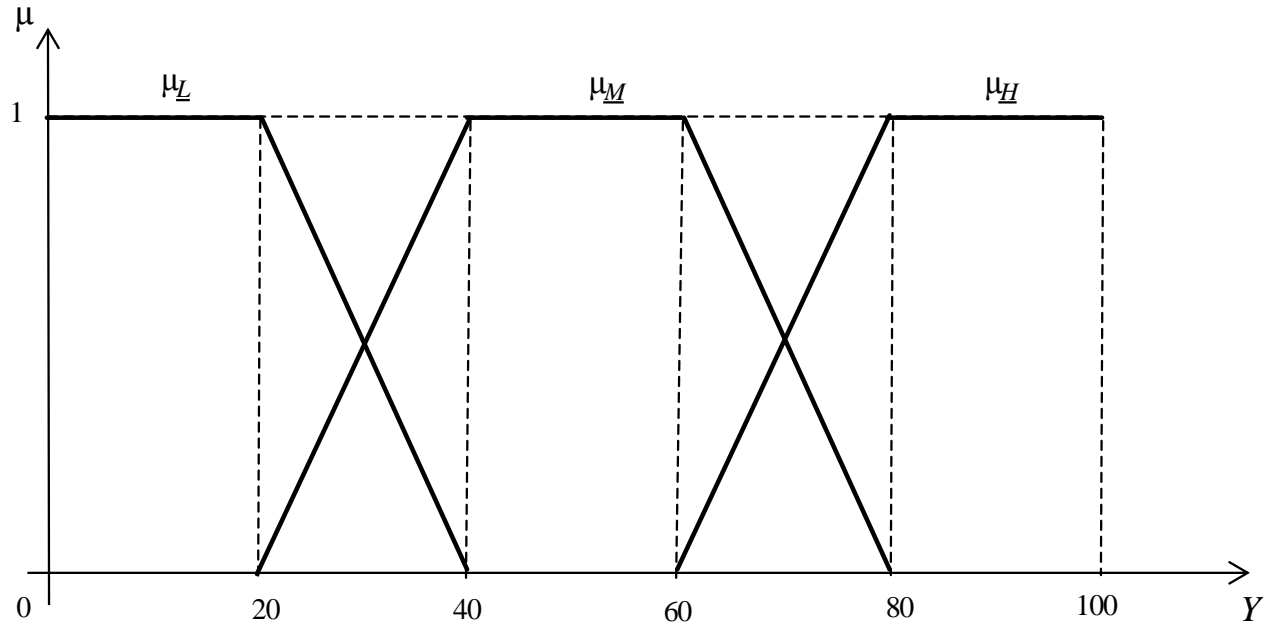

Source: Courses of the membership functions with even distribution of the points $a, b, c$, $d$ within the interval values $y \in Y=\langle 0,100\rangle$

Fig. 1: Courses of the membership functions with even distribution of the points $a, b, c, d$ within the interval values $y \in Y=\langle 0,100\rangle$

The following fuzzification table valid for $i=\mathrm{LTI}$, INV, UNE, whose elements are the values $\mu_{\underline{A i}}\left(u_{\mathrm{i}}\right)$, where index $\underline{A} \in\{\underline{L}, \underline{M}, \underline{H}\}$, is derived from the above stated equations and inequalities: 
Tab. 2: Fuzzification table valid for $i=L T I, I N V, U N E$

\begin{tabular}{|l|c|c|c|c|c|}
\hline Interval & $\boldsymbol{u}_{\boldsymbol{i}}<\mathbf{2 0}$ & $\mathbf{2 0} \leq \boldsymbol{u}_{\boldsymbol{i}}<\mathbf{4 0}$ & $\mathbf{4 0} \leq \boldsymbol{u}_{\boldsymbol{i}}<\mathbf{6 0}$ & $\mathbf{6 0} \leq \boldsymbol{u}_{\boldsymbol{i}}<\mathbf{8 0}$ & $\boldsymbol{u}_{\boldsymbol{i}} \geq \mathbf{8 0}$ \\
\hline $\boldsymbol{L}_{\boldsymbol{i}}$ & 1 & $\left(40-u_{i}\right) / 20$ & 0 & 0 & 0 \\
\hline $\boldsymbol{M}_{\boldsymbol{i}}$ & 0 & $\left(u_{i}-20\right) / 20$ & 1 & $\left(80-u_{i}\right) / 20$ & 0 \\
\hline $\boldsymbol{H}_{\boldsymbol{i}}$ & 0 & 0 & 0 & $\left(u_{i}-60\right) / 20$ & 1 \\
\hline
\end{tabular}

Source:Own

In the fuzzification table, only non-zero elements are taken into account, with the help of which the input vector $(100,100,100) \in U$ generates the set $X=\left\{\left(\underline{H}_{\mathrm{LTI}}, 1\right),\left(\underline{H}_{\mathrm{INV}}, 1\right),\left(\underline{H}_{\mathrm{UNE}}\right.\right.$, 1)\}. From its three elements only one element set $L F=\{(\underline{H}, \underline{H}, \underline{H})\}$ can be created. The triad $(\underline{H}, \underline{H}, \underline{H})$ of the input fuzzy sets of the projection $F$ assigns the output fuzzy set $\underline{H}$ according to the already mentioned strategy of the predominant element. For $\mu_{A G G}(y)=$ $\max \left\{\min \left\{\min \left\{\mu_{\underline{A} l}\left(x_{1}\right), \ldots, \mu_{\underline{A} n}\left(x_{n}\right)\right\}, \mu_{\underline{C}}(y)\right\}: \underline{C}=F\left(\underline{A}_{1}, \ldots, \underline{A}_{\mathrm{n}}\right),\left(\underline{A}_{1}, \ldots, \underline{A}_{\mathrm{n}}\right) \in L F\right\}$ it then applies $\mu_{\underline{A G G}}(y)=\max \left\{\min \left\{\min \{1,1,1\}, \mu_{\underline{H}}(y)\right\}\right\}=\max \left\{\min \left\{1, \mu_{\underline{H}}(y)\right\}\right\}=\mu_{\underline{H}}(y)$ (see the highlighted course of line in Fig. 2).

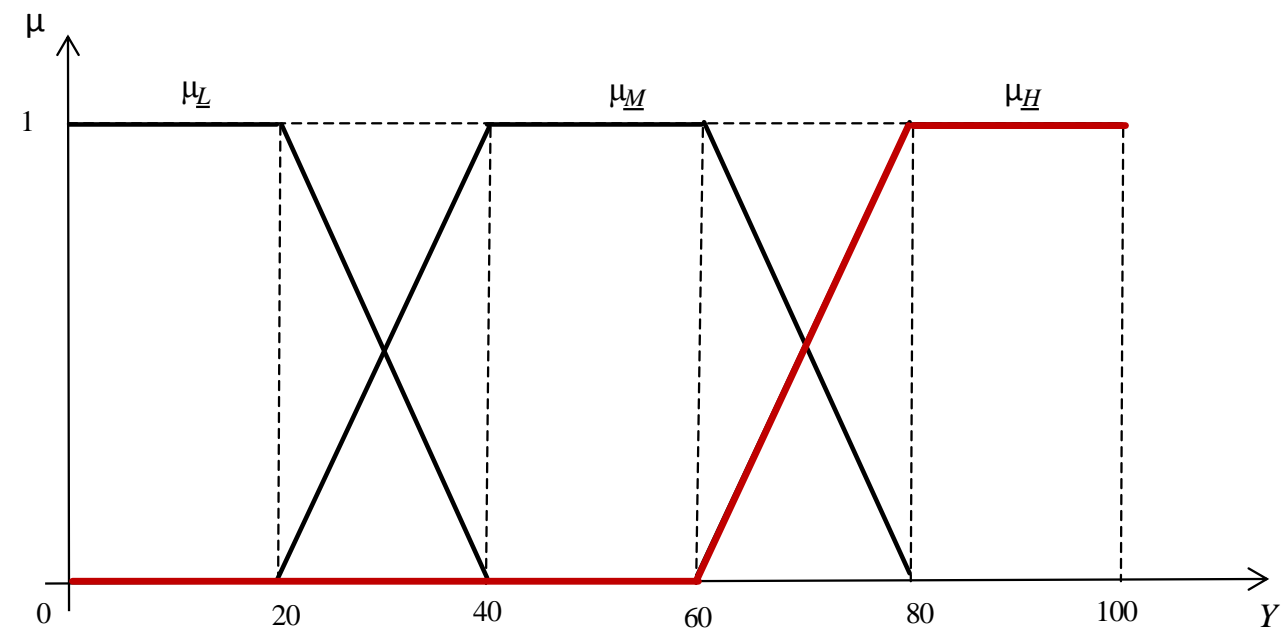

Source: Own

Fig. 2: The course of the membership function $\mu_{\underline{A G G}}$

For the certain integers values above the universe $Y$ in the formula (2) it applies: $\int y$. $\mu_{A G G}(y) \mathrm{d} y=2533, \int \mu_{\underline{A G G}}(y) \mathrm{d} y=30$, therefore $y_{0}=2533 / 30=84.4$. After recalculation $y_{0}$ to $\Delta \mathrm{GDP} \%$, we get the predicted value of $\Delta \mathrm{GDP} \%=(84.4 \cdot 1.5 / 100)+1 \approx 2.27$.

The predictive fuzzy model for $\mathbf{2 0 2 0}$ is based on the data of the 4-year period 2016-2019, with 2018 and 2019 (the highlighted columns) recording the econometric predictions of the respective values. For the conversion of the values of inputs given in 2019 in a general formula the same applies as we already encountered in 2017; again, we get the same vector $(100,100,100) \in U$ of recalculated inputs. All the operations with the fuzzy sets described above are repeated, $\mu_{A G G}$ coincides with $\mu_{\underline{H}}$ (see Fig. 2), with the result $y_{0}=84.4$, from which we get $\Delta \mathrm{GDP} \%=2.27$.

\section{$3 \quad$ Results Discussion}

Both of the predictive tasks had a trivial solution from the fuzzy model point of view. This results from the fact that in the monitored period the values of the observed variables accelerating the GDP growth rate increased monotonically and the values of the observed variables slowing the growth rate of GDP declined monotonously. 
Nevertheless, some differences can be identified in predictive fuzzy models for 2018 and 2020. The econometric forecast predicts a moderate deceleration in the GDP growth rate for 2019 compared to 2018 . This deceleration is not signaled by the uploaded data and thus, they did not enter in the fuzzy model.

The interpretation of this situation is that the econometric model utilizes the information that the fuzzy model does not work with. Regardless of whether or not experts who form the fuzzy model have this information, they should respond to the predicted slowdown according to experience gained by changing the interval of a priori expected values of $\triangle \mathrm{GDP} \%$. For example, by reducing $x_{\max }$ to 2.2 and increasing $x_{\min }$ to 1.1 . Then, by the reverse conversion of $y_{0}$ to $\Delta \mathrm{GDP} \%$ we obtain the predicted $\Delta \mathrm{GDP} \%=(84.4 \cdot 1.1 / 100)+1.1 \approx 2$ for the year 2020 , i.e., at the level of the econometric forecast for 2019.

\section{Conclusion}

The aim of the paper was to present a general fuzzy system for solving managerial problems operating under conditions of internal uncertainty of the model of the solved task and formulated within the Zadeh's fuzzy approach, offering subjectively expected values as an alternative to statistically expected values. The fuzzy system works in conjunction with knowledgeable experts who, inter alia, based on experience gained, determine the limits of the interval in which the resulting value can be a priori expected; within these limits, the fuzzy algorithm then finds the "right" value.

The theoretical basis of the fuzzy algorithm leans on the transformation of one of the important concepts of fuzzy logic, the so-called extension principle, to the level of the linguistic variables and their terms in which the problem is solved. The fuzzy algorithm is applied in predicting the GDP growth rate of Greece in 2018 (compared to the reported econometric forecast) and 2020 (a new contribution to the paper). The forecast default data are the components of the previous four-year evolution of the three macroeconomic indicators (long-term interest rates, investments and unemployment). These are used in the fuzzy model formulation phase within which experts get the opportunity to take into account their knowledge and experience. The process of solving a task is purely mechanical and independent of the human factor in which the data play the role of external inputs to the fuzzy algorithm.

Both of the predictive tasks had a trivial solution from the fuzzy model point of view that did not enable adequate demonstration of the technical complexity of the respective fuzzy operations. It resulted from the fact that in the monitored period the values of the observed variables accelerating the GDP growth rate increased monotonically and the values of the observed variables slowing the growth rate of GDP declined monotonously. However, they allowed the demonstration of one of the ways through which the experts can correct the deficiencies of the fuzzy algorithm. The deficiency here was the missing information originating from the source which the fuzzy algorithm did not work with; the correction option was a change of interval limits of a priori expected result values.

\section{Literature}

[1] BĚHOUNEK, L.; CINTULA, P.: From fuzzy logic to fuzzy mathematics: A methodological manifesto. Fuzzy Sets and Systems. 2006, 157(5): 642-646. DOI: $10.1016 /$ j.fss.2005.10.011

[2] BLOOM, N.: The impact of uncertainty shocks. Econometrica. 2009, 77(3): 623-685. DOI: $\underline{10.3982 / E C T A 6248}$ 
[3] CABRERIZO, F. J.; CHICLANA, F.; AL-HMOUZ, R.; MORFEQ, A.; BALAMASH, A. S.; HERRERA-VIEDMA, E.: Fuzzy decision making and consensus: Challenges. Journal of Intelligent \& Fuzzy Systems. 29(3), 1109-1118. DOI: 10.3233/IFS-151719

[4] COUNCIL OF THE EUROPEAN UNION: Greece: the third economic adjustment programme. [online]. 2019. [accessed 2019-01-22]. Available from WWW: https://www.consilium.europa.eu/en/policies/financial-assistance-eurozonemembers/greece-programme/

[5] DUBOIS, D.: Possibility theory and statistical reasoning. Computational Statistics \& Data Analysis. 2006, 51(1): 47-69. DOI: 10.1016/j.csda.2006.04.015

[6] DUBOIS, D.; PRADE, H.: What are fuzzy rules and how to use them. Fuzzy Sets and Systems. 1996, 84(2): 169-185. DOI: 10.1016/0165-0114(96)00066-8

[7] EUROPEAN ECONOMIC FORECAST. Institutional Paper 007/ May 2018. [online]. Luxembourg: Publications office for European Union, 2018. [accessed 2018-10-12]. Available from WWW: https://cdn.20m.es/adj/2018/05/03/3938.pdf

[8] OECD Data: Gross Domestic Product (GDP). [online]. 2018. [accessed 201-10-20]. Available from WWW: https://stats.oecd.org/Index.aspx?DatasetCode=SNA_TABLE1

[9] HAŠKOVÁ, S.; FIALA, P.: A fuzzy approach for the estimation of foreign investment risk based on values of rating indices. Risk Management. 2019, 21(3): 183-199. DOI: $10.1057 / \mathrm{s} 41283-019-00053-\mathrm{Z}$

[10] HERRERA, F.; HERRERA-VIEDMA, E.: Linguistic decision analysis: steps for solving decision problems under linguistic information. Fuzzy Sets and systems. 2000, 115(1), 67-82. DOI: $10.1016 / \mathrm{S} 0165-0114(99) 00024-X$

[11] HERRERA, F.; ALONSO, S.; CHICLANA, F.; HERRERA-VIEDMA, E.: Computing with words in decision making: foundations, trends and prospects. Fuzzy Optimization and Decision Making. 2009, 8(4), 337-364. DOI: 10.1007/s10700-009-9065-2

[12] OECD Data: Investment (GFCF). [online]. 2018. [accessed 2018-10-29]. Available from WWW: https://data.oecd.org/gdp/investment-gfcf.htm

[13] KAHNEMAN, D.: Maps of bounded rationality: Psychology for behavioral economics. American Economic Review. 2003, 93(5): 1449-1475. DOI: $10.1257 / 000282803322655392$

[14] KAHRAMAN, C. (editor): Fuzzy Multi-Criteria Decision Making: Theory and Applications with Recent Developments. Springer Science \& Business Media. eBook ISBN 978-0-387-76813-7. DOI: $10.1007 / 978-0-387-76813-7$

[15] KRUEGER, T.; PAGE, T.; HUBACEK, K.; SMITH, L.; HISCOCK, K.: The role of expert opinion in environmental modelling. Environmental Modelling \& Software. 36, 4-18. DOI: $10.1016 /$ j.envsoft.2012.01.011

[16] OECD Data: Long-term interest rates. [online]. 2018 [accessed 2018-11-22]. Available from WWW: https://data.oecd.org/interest/long-term-interest-rates.htm

[17] LÓPEZ-DUARTE, C.; VIDAL-SUÁREZ, M. M.: External uncertainty and entry mode choice: Cultural distance, political risk and language diversity. International Business Review. 2010, 19(6): 575-588. DOI: 10.1016/j.ibusrev.2010.03.007

[18] TIMMERMANS, M.; HEIJMANS, R., DANIELS, H.: Cyclical patterns in risk indicators based on financial market infrastructure transaction data. Quantitative Finance and Economics. 2018, 2(3): 615-636. DOI: 10.3934/QFE.2018.3.615 
[19] OECD Data: Unemployment rate. [online]. 2018. [accessed 2018-11-02]. Available from WWW: https://data.oecd.org/unemp/unemployment-rate.htm

[20] VOCHOZKA, M.; HORÁK, J.; ŠULEŘ, P.: Equalizing Seasonal Time Series Using Artificial Neural Networks in Predicting the Euro-Yuan Exchange Rate. Journal of Risk and Financial Management. 2019, 12(2): 76. DOI: 10.3390/jrfm12020076

[21] ZADEH, L. A.: Outline of a New Approach to the Analysis of Complex Systems and Decision Processes. IEEE Transactions on Systems, Man, and Cybernetics. 1973, 3(1): 28-44. DOI: $\underline{\text { 10.1109/TSMC.1973.5408575 }}$

[22] ZADEH, L. A.: Fuzzy logic = computing with words. IEEE Transactions on Fuzzy Systems. 1996, 4(2): 103-111. DOI: 10.1109/91.493904

Ing. Simona Hašková, Ph.D. 


\section{ALTERNATIVNÍ PŘÍSTUP K ODHADU TEMPA RŮSTU HDP: FUZZY PREDIKČNÍ MODEL}

Nepřesnost předpovědí tempa růstu HDP je způsobena nedostatkem informací potřebných $\mathrm{k}$ odstranění nejistoty. Cílem příspěvku je v krátkém období předpovědět tempo růstu HDP fuzzy metodou; ta je vhodným nástrojem pro analýzu problémů zatížených nejistotou. Za tím účelem bude nejprve stručně diskutována vhodnost fuzzy př́stupu $\mathrm{v}$ porovnání se statistickými metodami $\mathrm{v}$ nedeterministických př́padech. Základní principy teorie fuzzy množin jsou popsány a následně použity v predikci tempa růstu HDP v Řecku pro roky 2018 (ve srovnání s oficiální ekonometrickou prognózou) a 2020 (přínos příspěvku). Krátkodobá prognóza se opírá o vstupní složky předchozího čtyřletého vývoje tř́i makroekonomických ukazatelů (úrokové sazby, investic a nezaměstnanosti), které jsou základními vstupními parametry modelu. Výsledky fuzzy predikce neprokázaly významné odchylky od statistických předpovědí. Nicméně monotónní vývoj vstupních dat modelu nám umožnil demonstrovat jeden ze způsobů, jak mohou odborníci korigovat nedostatky fuzzy algoritmu.

\section{EIN ALTERNATIVER ANSATZ ZUR SCHÄTZUNG DER WACHSTUMSRATE BIP: DAS FUZZY-PRÄDIKATIONSMODELL}

Die Ungenauigkeit der BIP-Wachstumsprognosen ist auf den Mangel an Informationen zurückzuführen, die zur Beseitigung der Unsicherheit erforderlich sind. Das Ziel der Artikel ist die BIP-Wachstumsrate unter Verwendung der Fuzzy-Methode kurzfristig vorherzusagen; es ist ein geeignetes Instrument zur Analyse von mit Unsicherheit verbundenen Problemen. Hierzu wird zunächst kurz auf die Eignung des Fuzzy-Ansatzes im Vergleich zu statistischen Methoden in nicht deterministischen Fällen eingegangen. Die Grundprinzipien der FuzzyMengen-Theorie werden beschrieben und anschließend in der Vorhersage der BIPWachstumsrate in Griechenland für 2018 und 2020 verwendet. Die kurzfristige Prognose basiert auf den Inputkomponenten der vorangegangenen vierjährigen Entwicklung von drei makroökonomischen Indikatoren, die grundlegenden Inputparameter des Modells darstellen. Die Ergebnisse der Fuzzy-Vorhersage zeigten keine signifikanten Abweichungen von den statistischen Prognosen. Die monotone Entwicklung der Eingabedaten des Modells hat es uns jedoch ermöglicht, einen Weg aufzuzeigen, wie Experten Unzulänglichkeiten von FuzzyAlgorithmen korrigieren können.

\section{ALTERNATYWNE PODEJŚCIE DO SZACOWANIA TEMPA WZROSTU PKB: ROZMYTY MODEL PROGNOSTYCZNY}

Niedokładność prognoz wzrostu PKB wynika z braku informacji niezbędnych do usunięcia niepewności. Celem artykułu jest prognozowanie tempa wzrostu PKB w krótkim okresie przy użyciu metody fuzzy; jest odpowiednim narzędziem do analizy problemów związanych $\mathrm{z}$ niepewnością. $\mathrm{W}$ tym celu $\mathrm{W}$ skrócie zostanie omówiona przydatność podejścia rozmytego $\mathrm{W}$ porównaniu $\mathrm{z}$ metodami statystycznymi $\mathrm{w}$ przypadkach niedeterministycznych. Podstawowe zasady teorii zbiorów rozmytych zostały opisane, a następnie wykorzystane w prognozowaniu tempa wzrostu PKB w Grecji na 2018 r. i 2020 r. Prognoza krótkoterminowa opiera się na elementach wejściowych poprzedniego czteroletniego rozwoju trzech wskaźników makroekonomicznych, które są podstawowymi parametrami wejściowymi modelu. Wyniki prognozy rozmytej nie wykazały istotnych odchyleń od prognoz statystycznych. Jednak monotonne opracowanie danych wejściowych modelu pozwoliło nam zademonstrować jeden ze sposobów, w jaki eksperci mogą poprawić niedociągnięcia algorytmu rozmytego. 